\title{
Colorado Potato Beetle, Leptinotarsa decemlineata (Say) and False Potato Beetle, Leptinotarsa juncta (Germar) (Insecta: Coleoptera: Chrysomelidae) ${ }^{1}$
}

Richard L. Jacques, Jr. ${ }^{2}$

\section{Introduction}

True "potato beetles" are members of the beetle genus Leptinotarsa, with 32 species in North America, including Mexico; 10 species in the continental United States, including two species in Florida. The most notable is the Colorado potato beetle, Leptinotarsa decemlineata (Say), found in Florida and most of the United States, and introduced into Europe and parts of Asia. It is a serious pest of potatoes and other solanaceous plants.

The family Chrysomelidae, or leaf beetles, is one of the seven largest families of Coleoptera. All members are phytophagous, both as larvae and as adults. Some feed on roots, others on stems or leaves of herbaceous plants, and some mine the leaves of woody plants. They belong to the subfamily Chrysomelinae represented by over 2,000 species distributed throughout the world. Most larvae of the Chrysomelinae live openly on plants while feeding, and they usually burrow into soil to pupate. Many economically important species are found in this subfamily.

\section{History}

The Colorado potato beetle was first discovered by Thomas Nuttal in 1811 and described in 1824 by Thomas Say from specimens collected in the Rocky Mountains on buffalo-bur, Solanum rostratum Ramur. The insect's association with the potato plant, Solanum tuberosum (L.), was not known until about 1859 when it began destroying potato crops about 100 miles west of Omaha, Nebraska. The insect began its rapid spread eastward, reaching the Atlantic coast by 1874 . The evolution of the name Colorado potato beetle is curious since the beetle did not originate in Colorado but is believed to have originated in central Mexico. It had a series of names from 1863 to 1867 , including the "ten-striped spearman," "ten-lined potato beetle," "potato-bug" and "new potato bug." Colorado was not connected to the insect until Walsh (1865) stated that two of his colleagues had seen large numbers of the insect in the territory of Colorado feeding on buffalo-bur. This convinced him that it was native to Colorado. It was C.V. Riley (1867) who first used the combination: Colorado potato beetle.

1. This document is EENY-146 (originally published as DPI Entomology Circular 271), one of a series of Featured Creatures from the Entomology and Nematology Department, Florida Cooperative Extension Service, Institute of Food and Agricultural Sciences, University of Florida. Published: July 2000. Revised: August 2003. This document is also available on Featured Creatures Website at http://creatures.ifas.ufl.edu. Please visit the EDIS Website at http://edis.ifas.ufl.edu. Additional information on these organisms, including many color photographs, is available at the Entomology and Nematology Department website at http://entnemdept.ifas.ufl.edu/.

2. Richard L. Jacques, Jr., Florida Department of Agriculture and Consumer Services, Division of Plant Industry, Gainesville, FL.

The Institute of Food and Agricultural Sciences is an equal opportunity/affirmative action employer authorized to provide research, educational information and other services only to individuals and institutions that function without regard to race, color, sex, age, handicap, or national origin. For information on obtaining other extension publications, contact your county Cooperative Extension Service office. Florida Cooperative Extension Service/Institute of Food and Agricultural Sciences/University of Florida/Christine Taylor Waddill, Dean. 


\section{Distribution}

Leptinotarsa decemlineata occurs in most areas of the United States, including Florida, where it was first reported in 1920. In Florida, as of 1985, the beetle was reported in the following counties: Alachua, Baker, Brevard, Clay, Duval, Escambia, Gadsden, Gilchrist, Hamilton, Hardee, Highlands, Hillsborough, Holmes, Indian River, Jefferson, Lake, Levy, Liberty, Marion, Okaloosa, Orange, Palm Beach, Polk, Putnam, St. John's, Santa Rosa, Sumter and Volusia. It was collected in Belle Glade (Palm Beach County) in 1947, but has not been reported there since. The southernmost record in peninsular Florida is Vero Beach (Indian River County) on the eastern shore and Crewsville (Hardee County), and DeSoto City (Highlands County) in the south-central part of the state.

Leptinotarsa juncta is found primarily in the southeastern United States from northern Florida to eastern Texas, north to Missouri, southern Illinois and Indiana, and east to Maryland and Virginia. Florida records (DPI), as of 1985, are from Alachua, Jackson, Jefferson and Leon counties.

\section{Description}

The genus Leptinotarsa is assigned to the tribe Doryphorini containing three genera in the United States, recognized by having the procoxal cavities open behind, simple claws separate at base and usually divergent. Species of Leptinotarsa are recognized by the following features: maxillary palpi with apical segment shorter than preceding, truncate; mesosternum not raised above the level of prosternum; profemur of male simple.

Two species of Leptinotarsa occur in Florida: $L$. decemlineata, the Colorado potato beetle, and $L$. juncta (Germar), the false potato beetle. The latter incorrectly has been called the "false Colorado potato beetle" because of its similarity to $L$. decemlineata. $L$. decemlineata has pale yellow elytra, outlined in black; each elytron (forewing cover in beetles) with five vittae (broad longitudinal stripes); vitta 1 shorter than other four and adjacent to the sutural margin; vittae 2 thru 5 extending more than half the length of the elytron and very distinct; punctation coarse in irregular rows. L. juncta with pale yellow elytra, with

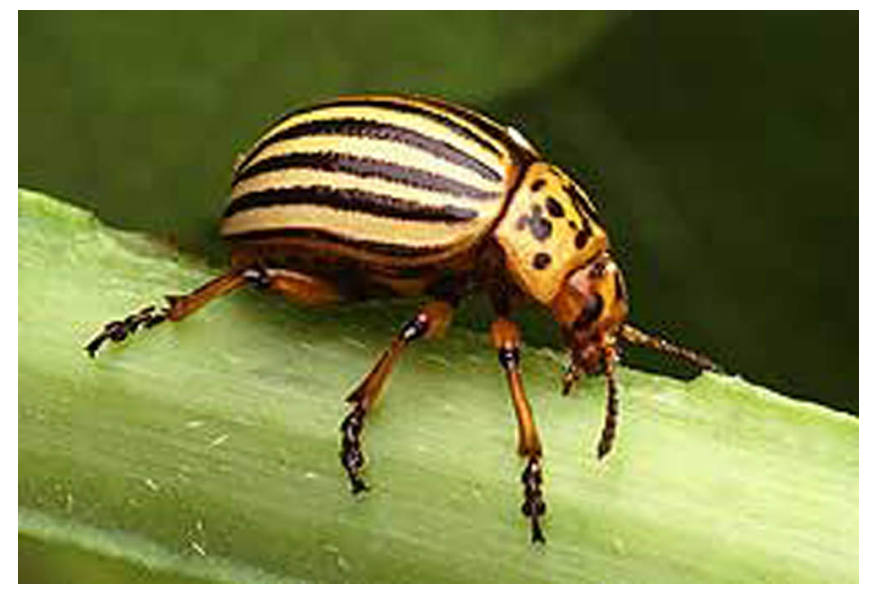

Figure 1. Adult Colorado potato beetle, Leptinotarsa decemlineata (Say). Credits: Scott Bauer, USDA

five black vittae; vitta 1 bordering sutural margin, extending from just below the base to the apex; vitta 2 shorter than first, not reaching base; vitta 3 and 4 connecting at apex of elytron; space between black; vitta 5 along lateral margin of elytron; punctation coarse, in very regular rows outlining each vitta. Distinct black spot on outer margin of femur. Larva of the Colorado potato beetle are 1/2 inch long when mature. Adults measure about $3 / 8$ inch long.

\section{Life Cycle}

The life cycle of the Colorado potato beetle starts with the adult as the overwintering stage. They dig into the soil to a depth of several inches and emerge in the spring. They feed on newly sprouted host plants where they mate. Females deposit bright orange oval eggs on the surface of the host plant's leaves, usually on the undersurface protected from direct sunlight. An egg mass may contain from 10 to 40 eggs, and most adult females deposit over 300 eggs during a period of four to five weeks. Eggs hatch in four to five days depending in part on temperature and humidity. The four larval instars last a total of 21 days. The small, cyphosomatic, reddish larvae feed almost continuously on the leaves of the host plant, stopping only when molting. At the end of the larval period they drop from the plants and burrow into the soil where they construct a spherical cell and transform into a yellowish pupa. This lasts from five to 10 days. There are one to three generations per year, depending on latitude. The life cycle of the false potato beetle is similar to that of the Colorado potato beetle. Eggs hatch in four to five days and the larvae 
feed on the leaves of the host plants. There are four larval instars lasting 21 days. The larvae drop to the soil to pupate, and pupation lasts 10 to 15 days.

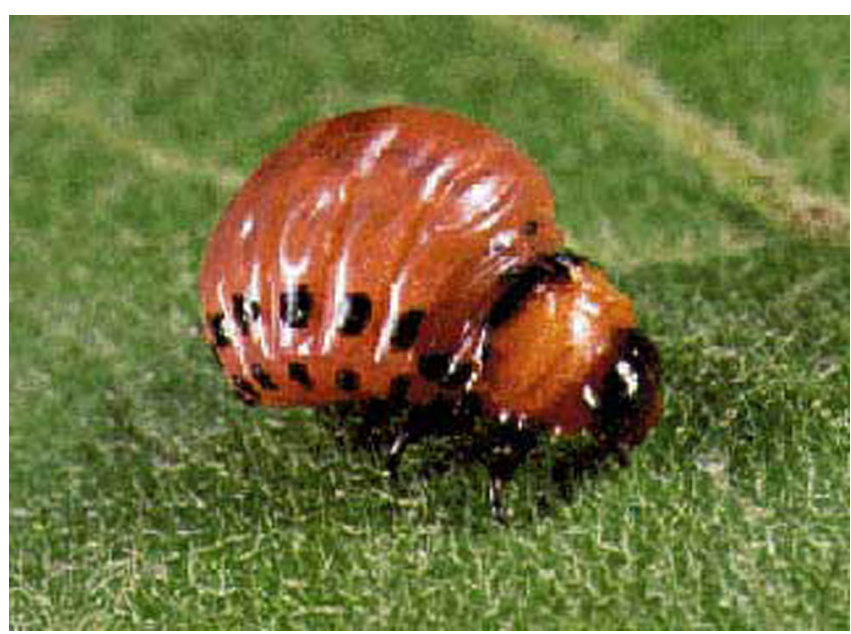

Figure 2. Larva of the Colorado potato beetle, Leptinotarsa decemlineata (Say). Credits: University of Florida

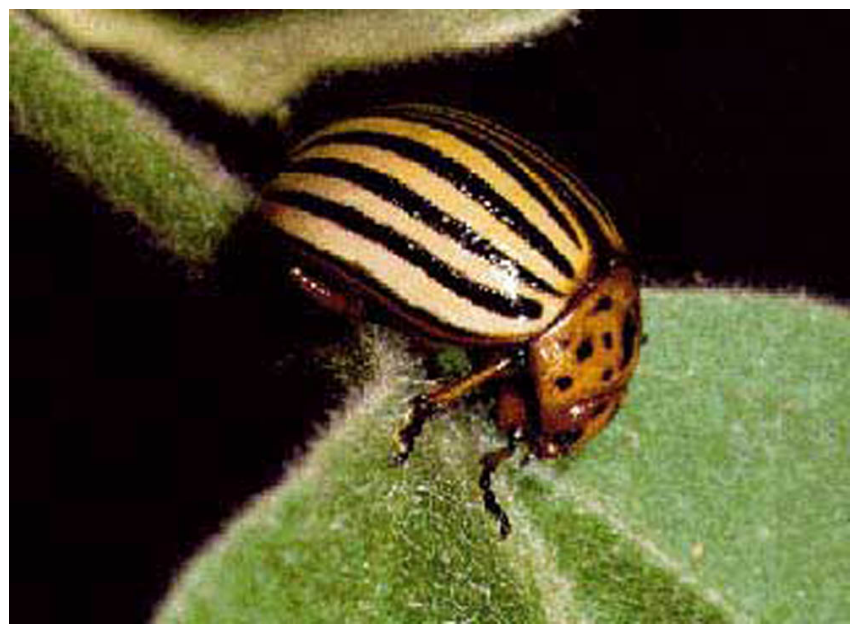

Figure 3. Adult Colorado potato beetle, Leptinotarsa decemlineata (Say). Credits: University of Florida

\section{Hosts}

Potatoes are the preferred host for the Colorado potato beetle, but it may feed and survive on a number of other plants in the nightshade family: eggplant, tomato, pepper, tobacco, ground cherry, horse-nettle, common nightshade, belladonna, thornapple, henbane, and its first recorded host plant.

The false potato beetle is found primarily on the common noxious weed, horse-nettle, Solanum carolinense L. It also feeds on other solanaceous plants, such as species of ground cherry or husk tomato, Physalis spp., and common nightshade, Solanum dulcamara (L.).

\section{Key to the Leptinotarsa Species of Florida}

Elytral punctation in regular rows from base to apex, vitta 3 and 4 connect at apex of elytron, space between black; black spot on outer margin of the femur. (southeastern U.S.).... juncta (Germar).

Elytral punctation irregular, not forming regular rows, no black space between vitta 3 and 4; no black spot on legs. (widespread)..... decemlineata (Say).

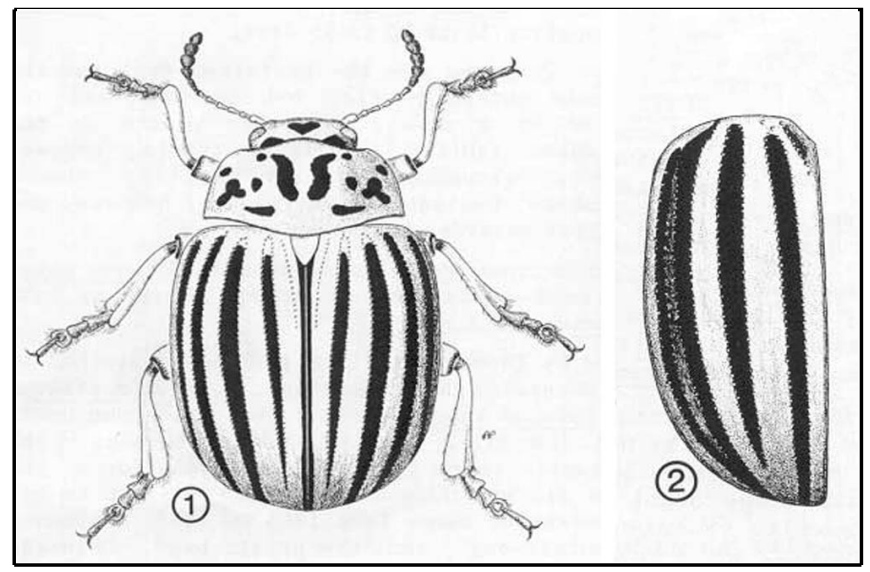

Figure 4. Comparisons of the elytrons of adult Colorado potato beetle, Leptinotarsa decemlineata (Say) (1), and false potato beetle, Leptinotarsa juncta (Germar) (2). Credits: Division of Plant Industry

\section{Management}

See: Insect Management Guide for Vegetables

\section{Selected References}

Arnett Jr RH. 1963. The beetles of the United States. Catholic University of America Press, Washington. $1112 \mathrm{p}$.

Gauthier NL, Hofmaster R, Semel M. 1981. History of Colorado potato beetle control. In Advances in Potato Pest Management. J.H. Lashomb and R. Casagrande (eds.). Hutchinson Ross Publishing Company, Stroudsburg, PA.

Heiser C. 1969. Nightshades: the Paradoxical Plants. W.H. Freeman and Co., San Francisco. 200 p. 
Jacques Jr RL. 1972. Taxonomic Revision of the Genus Leptinotarsa (Coleoptera: Chrysomelidae) of North America. Xerox University Microfilms, Ann Arbor, MI. 180 p.

Pope RD, Madge RB 1984. The 'when' and 'why' of the 'Colorado potato beetle'. Bulletin of the Entomological Society of London 8: 175-177.

Riley CV. 1867. The Colorado potato-beetle. Prairie Farmer 20: 389.

Walsh BD. 1865. The new potato bug, and its natural history. The Practical Entomologist 1: 1- 4. 